\title{
4.6 Диверсифікація основних напрямків державного регулювання в АПК
}

У зв'язку з посиленням конкурентних засад в сільському господарстві країни на провідний план виходять стійкість положення підприємства на ринку сільгосппродуктів, конкурентоспроможність, економічна ефективність і ефективність. Постійний пошук раціональної моделі виживання і подальшого розвитку сільськогосподарського підприємства в умовах мінливості кон'юнктури в частині купівельного попиту і освоєння вигідних товарних ніш на ринку сільгосппродуктів обумовлює зростання ролі диверсифікації виробництва як фактору протистояння ринковим катаклізмам, коливаням купівельного попиту.

Правильне формування стратегії i тактики сільськогосподарського підприємства визначає тип диверсифікації, особливості спеціалізації, концентрації та інтенсифікації виробництва. Разом з тим у вітчизняній теорії управління та економіки проблеми диверсифікації поки ще залишаються недостатньо дослідженими, що не дозволяє в максимальному ступені реалізувати резерви іï ефективності в аграрному виробництві.

У статті аналізуються переваги стратегій диверсифікації для зниження ризиків, зокрема, агропідприємств в умовах дії правил і в цілому висока нестабільність сучасної економічної ситуації в Україні. Запропоновано заходи щодо посилення ефектів диверсифікації.

Одним 3 пріоритетних напрямків економічних досліджень в зв'язку 3 необхідністю адаптації агропромислового комплексу в світовому господарстві $є$ осмислення взаємозв'язку конкурентоспроможності, стратегії інноваційної диверсифікації, інституційного регулювання. Методи посилення конкурентних переваг та інституційної підтримки повинні бути адаптовані до умов функціонування України в СОТ 3 використанням традиційних i нових методологічних підходів: аналізу, синтезу, моделювання, інформатизації, експертних оцінок та ін.

Стратегія диверсифікації є найбільш ефективною для розвитку інноваційних бізнесів в рамках агропромислового комплексу. В умовах економічної 
модернізації економіки в зв'язку з необхідністю іï перекладу на інноваційний шлях розвитку найбільш доцільне використання стратегії диверсифікації з метою забезпечення стійкості до оновлення сучасних агропромислових комплексів. Диверсифіковані напрямки інноваційної діяльності забезпечують конкурентні переваги на світових ринках: зниження інноваційних ризиків, економічне зростання, скорочення витрат при диверсифікації галузі. Досвід стратегічного управління диверсифікованими структурами в інших країнах показав, що він цілком може бути застосовний в умовах модернізації українського сільського господарства інноваційним шляхом розвитку. [158]

Необхідність та перспективність впровадження диверсифікації як альтернативної стратегічної орієнтації підприємств обгрунтували такі зарубіжні науковці, як М. Портер, Ф. Котлер, Г. Амстронг, А. Кукарцева.

Потенціал економічного зростання аграрної сфери за рахунок диверсифікованого виробництва є об’єктом досліджень І. Гришової, В. Ткачука, О. Томіліна, Н. Степаненко.

Переваги та можливі загрози диверсифікації підприємств, зокрема аграрних, описані в працях Д. Дея, Н. Маслак, О. Лемішко, А. Семенов, І. Іщенко, Ф. Важинського, М. Корінько, Л. Лозовського, В. Лебедевої, Т. Панюк.

Проте означені питання не можна вважати вичерпаними та достатньо розкритими, тому пошук ефективних механізмів і методів їх розв'язання й надалі становить неабиякий інтерес для аграрної науки та господарської практики.

Диверсифікація як форма економічних зв'язків економічних суб'єктів $є$ закономірністю існування та інноваційного розвитку агропромислових систем.

У свою чергу, диверсифікація має свої закономірності розвитку:

- вирівнювання галузевої рентабельності,

- усунення диспропорцій аграрного відтворення,

- трансформація і динамічна стійкість.

Ефект диверсифікації виражається в появі нових видів продукції і послуг, зміні галузевих, міжгалузевих та регіональних пропорцій. Диверсифікація може 
здійснюватися з метою отримання ефекту масштабу виробництва та розширення видів діяльності.

В АПК диверсифікація здійснюється шляхом вертикальної інтеграції сільськогосподарських товаровиробників та підприємств промислової переробки, організацій, що надають фінансові послуги - виробниче i інвестиційне спрямування, розуміється як розширення масштабів діяльності. У сільському господарстві поширені: горизонтальна, конгломератна диверсифікація. Основними видами стратегії диверсифікації в АПК є диверсифікація по продукту і по регіону [160].

Для кількісної оцінки диверсифікації використовуються показники: широта диверсифікації, коефіцієнт пов'язаної диверсифікації, масштаб диверсифікації. Ефект диверсифікації виходить за межі аграрного сектора економіки. Необхідність модернізації економіки в умовах кризи сільського господарства, функціонування в СОТ вимагає посилення конкурентних позицій агропромислового комплексу України на шляху його інноваційного розвитку. Низька інноваційна сприйнятливість АПК, втрата значної частини науковотехнічного потенціалу, негативні аспекти стану світової економіки вимагають здійснення заходів щодо вдосконалення управління в аграрному секторі, принципово нового підходу, що відображає вплив зовнішніх i внутрішніх факторів інноваційного розвитку, їх взаємодії з державним регулюванням.

Стратегія інноваційної диверсифікації є ефективною для великих структур. Різноманіття видів даної стратегії дозволяє кожній компанії знайти таку модель розвитку, яка підходить саме їй, сприяє стійкості до оновлення. Диверсифіковані напрямки інноваційної діяльності забезпечують конкурентні переваги. Інноваційної формою диверсифікації $\epsilon$ кластери, що складаються 3 конкурентоспроможних економічних суб'єктів в рамках окремих галузей i локальних утворень. Однак розвиток ефективних диверсифікованих кластерів можливий тільки при наявності ефективної регіональної стратегії, оскільки їх розвиток у відриві від регіону неефективний. 
Кластер являє собою комплекс на базі галузевої або територіальної концентрації і диверсифікації мереж виробників, постачальників і споживачів, пов'язаних єдиним технологічним ланцюжком. У кластер входять також інфраструктурні організації, забезпечують сервісні, логістичні, науково-дослідні послуги [161].

Управління в інноваційних кластерах забезпечує ефективність диверсифікації відтворювальних процесів у сільському господарстві, що означає створення оптимальних відтворювальних пропорцій, безпосередньо залежить від ефективності диверсифікації мікроекономічних систем. Синергетичний ефект диверсифікації полягає в отриманні більшого чистого прибутку диверсифікованою системою, ніж сума чистих прибутків, що входять до їі складу окремих господарських систем, які діють самостійно. Складовими синергічного ефекту є: економія інвестицій, економія витрат, економія часу відтворювального процесу.

Особливостями функціонування агропромислового комплексу полягає в низькому рівні диверсифікаційних процесів, локалізації виробництв, недостатній фінансовій підтримці інновацій. Дія сукупності зазначених факторів і особливостей обумовлює специфіку заходів посилення конкурентних позицій АПК на макро, мезо і мікрорівні.

Серед заходів важливе значення мають: підтримка олігопольних ринків, підтримка експорту вітчизняного продовольства, високотехнологічних виробництв, вдосконалення діяльності територіальних торгових палат по сертифікації і стандартизації сільськогосподарської продукції, стимулювання диверсифікації сільськогосподарського і продовольчого ринків за рахунок розвитку середнього і малого підприємництва, ринкової інфраструктури банківських, страхових, рекламних, транспортних, торговельних послуг, імпортозамещенія.

Підтримуючі заходи повинні бути спрямовані інституційними структурами на формування необхідних умов для подолання інноваційної паузи, розвитку цивілізованої конкуренції, зниження підприємницьких ризиків. Важливо 
встановити заборону на контракти з продажу та лізингу основних фондів і товарів, якщо їх умови про обмеження взаємопов'язаних продажів послаблюють конкуренцію. Особливо актуальними $є$ заходи 3 розвитку інформаційноаналітичної та інноваційної інфраструктур, створенню умов для взаємодії інфраструктурних та підприємницьких виробничих компонентів. Для цього необхідна диверсифікація програм інфраструктурного забезпечення підприємництва в АПК [158].

Виявлення сучасних тенденцій диверсифікації, що супроводжується зміною структури організації виробництва, сприяє методика встановлення кількісної залежності в родинних і неспоріднених галузях сільськогосподарського виробництва, в якій міститься розрахунок інтегрального показника, значення якого свідчить про структурні зміни всередині галузі. Показник допомагає оцінити характер структурних зрушень між виробничими, але непов'язаними галузями - рослинництвом і тваринництвом, між профільними і непрофільними видами діяльності. Розрахунки інтегральних показників підтверджують наявність різних рівнів диверсифікації, причому переваги подальшого розвитку мають регіони з більш високим показником. Поєднання в одній господарській системі декількох видів діяльності неминуче призводить до інституційної диверсифікації - в сфері державної підтримки та надання фінансових послуг. Диверсифікація реалізується шляхом надання кредитних ресурсів для різних видів діяльності, використання бюджетних коштів на фінансування заходів держпідтримки сільськогосподарських товаровиробників.

Необхідні диверсифікація в сфері надання держпідтримки і кредитних ресурсів в АПК з різних видів діяльності, використання бюджетних коштів на фінансування вищезазначених заходів, зокрема, на продукцію, придбану сільськогосподарськими виробниками на умовах лізингу.

Держпідтримка повинна бути спрямована на поглиблення внутрішньогалузевої спеціалізації і спорідненої диверсифікації, стимулювання розвитку малих форм господарювання 3 метою посилення функціональної диверсифікації. 
В сучасних умовах звужується диверсифікація в результаті концентрації кредитних ресурсів, виданих великим сільгосппідприємствам у формі ТОВ - 7385\% від загального обсягу виданих кредитів, підвищується концентрація i поглиблюється спеціалізація кредитних послуг банками. Необхідно стимулювати диверсифікацію банківських послуг з метою розширення доступу сільських товаровиробників до кредитно фінансових ресурсів на основі розширення банківської мережі і кредитних кооперативів в сільській місцевості. У переліку послуг сільським виробникам, включеним в систему державних стандартів, розробка якої передбачена в Концепції сталого розвитку сільських територій, слід передбачити надання банківських послуг на стаціонарній основі в залежності від кількості сільського населення в регіонах, що може бути забезпечено шляхом державного замовлення на послугу серед кредитних організацій на конкурсній основі. Посилення конкурентних позицій агропромислового комплексу на основі кластеризації як інноваційного варіанта диверсифікації пов'язано з кон'юнктурою конкретного ринку, рівнем взаємозв'язку зовнішніх і внутрішніх факторів і їх впливів на попит, взаємодією чинників державного регулювання та інституційної підтримки.

У зв'язку з цим надзвичайно важливо встановлення ієрархічної зв'язку між конкурентним позиціонуванням, інституційним регулюванням, диверсифікацією діяльності, інтеграцією інноваційних програм технологічної модернізації агропромислового комплексу.

Елементи i структурно-організаційні зв'язки механізму посилення конкурентних позицій сільськогосподарських товаровиробників незалежно від ієрархічності ланок світового сільськогосподарського ринку повинні бути модифіковані для реалізації стратегії інноваційної диверсифікації діяльності у вигляді освіти інноваційних кластерів 3 метою модернізації економіки інноваційним шляхом розвитку. 